\title{
Leisure-time, occupational, and commuting physical activity and the risk of chronic kidney disease in a working population: a prospective cohort study
}

Shohei Yamamoto ( $\nabla$ syamamoto@hosp.ncgm.go.jp )

National Center for Global Health and Medicine https://orcid.org/0000-0001-6503-8577

Yosuke Inoue

Kokuritsu Kenkyu Kaihatsu Hojin Kokuritsu Kokusai Iryo Kenkyu Center

Keisuke Kuwahara

Teikyo Daigaku

Takako Miki

Kokuritsu Kenkyu Kaihatsu Hojin Kokuritsu Kokusai Iryo Kenkyu Center

Tohru Nakagawa

Hitachi Health Care Center

\section{Toru Honda}

Hitachi Health Care Center

Shuichiro Yamamoto

Hitachi Health Care Center

Takeshi Hayashi

Hitachi Health Care Center

Tetsuya Mizoue

Kokuritsu Kenkyu Kaihatsu Hojin Kokuritsu Kokusai Iryo Kenkyu Center

\section{Research}

Keywords: physical activity, sedentary behavior, chronic kidney disease, occupational health

Posted Date: July 27th, 2020

DOI: https://doi.org/10.21203/rs.3.rs-47441/v1

License: (c) (i) This work is licensed under a Creative Commons Attribution 4.0 International License. Read Full License 


\section{Abstract \\ Background:}

Very few attempts have been made to examine the association of leisure-time physical activity with chronic kidney disease (CKD) onset. In addition, there is no prospective information on the relationship between other domains of physical activity and CKD. In this study, we examined the risk of CKD in the context of leisure-time, occupational, and commuting physical activity.

\section{Methods:}

This prospective cohort study included 17,331 Japanese workers (aged 20-65 years at baseline) without CKD who were followed from 2006 to 2020. Leisure-time, occupational physical activity, and the duration of walking to and from work were assessed by a questionnaire at baseline. Incident CKD was defined as estimated glomerular filtration rate < $60 \mathrm{~mL} / \mathrm{min} / 1.73 \mathrm{~m}^{2}$ and/or proteinuria $[1+, 2+$, or $3+]$ by dipstick. Cox proportional hazard regression models were used to estimate the hazard ratios (HRs) and 95\% confidence intervals (Cls) of CKD.

\section{Results:}

During 147,752 person-years of follow-up, 4,013 participants developed CKD. After controlling for a wide range of covariates, leisure-time physical activity and walking for commute were not associated with CKD onset. By contrast, compared to the participants mostly engaging in sedentary work, those with standing/walking and fairly active work had HRs of 0.86 (95\% Cl: $0.79-0.94)$ and 0.87 (95\% Cl: $0.76-1.00)$ to develop CKD, respectively, after adjusting for all covariates including the other forms of physical activity ( $p$ for trend $=0.01$ ).

\section{Conclusions:}

Occupational physical activity was associated with the risk of CKD, and leisure-time and commuting physical activity were not.

\section{Background}

Chronic kidney disease (CKD) is an increasing clinical and public health problem; it is a precursor for end-stage renal disease and a strong risk factor for cardiovascular morbidity and mortality [1, 2]. In 2017, the global prevalence of CKD was $9.1 \%$, equivalent to approximately 700 million cases [1]. Few effective cure is available to treat patients with CKD; thus, the focus has been on the prevention of CKD incidence $[3,4]$. Thus far, the literature has revealed that CKD shares several established risk factors (i.e., diabetes, hypertension, and obesity) with cardiovascular diseases [5].

Physical activity is another important factor known to reduce cardiovascular risk [6] and is hypothesized to be an important modifiable risk factor in the development of CKD, either directly or indirectly through favorable effects on diabetes, hypertension, and obesity $[7,8]$. Although physical inactivity has been reported as a risk factor of CKD in several cross-sectional studies [9-12], evidence from prospective studies has been limited and inconsistent [10,11, 13]. The Australian Diabetes, Obesity, and Lifestyle (AusDiab) Study and the Health, Aging, and Body Composition (Health $A B C)$ study have demonstrated that physical activity was not associated with risk of incident CKD [10, 11]. By contrast, 
in a Taiwan cohort, a higher level of habitual physical activity was found to be associated with a lower risk of developing CKD [13].

In addition to the inconsistency in the association between physical activity and CKD, several other issues have not been addressed. First, cohort studies have focused on leisure-time physical activity alone or total physical activity (i.e., a combination of leisure-time and occupational physical activity) $[10,11,13]$, but there is no evidence for the association in relation to other domains of physical activity, such as occupational or commuting physical activity. For a considerable fraction of the general population, work constitutes the main setting for physical activity [14]. Thus, the importance of work-related physical activity for CKD risk should be clarified in this population. Second, it remains unknown whether the physical activity-CKD association differs according to health status that proposed as increasing the risk of CKD (i.e., diabetes, hypertension, or obesity). Such data are essential for revealing the biological interaction between physical activity and these health conditions concerning CKD onset. Last, according to our review of the literature, this study is the first to report on this issue based on prospective cohort studies in the Japanese population, which has one of the highest prevalence of $\operatorname{CKD}[15,16]$ and insufficient rates of physical activity.

To address these issues, we prospectively investigated the associations of leisure-time, occupational, and commuting physical activity with the risk of incidence of CKD in a large-scale cohort of the Japanese working population. We also analyzed the potential effect modification by a particular disease or condition or the other domains of physical activity based on the relation between 3 domains of physical activity and CKD.

\section{Methods}

\section{Study design}

This study was conducted as a part of the Japan Epidemiology Collaboration on Occupational Health (J-ECOH) Study, an ongoing large-scale cohort study among workers from multiple industries in Japan. The details of the J-ECOH Study and this study cohort have been described elsewhere $[17,18]$. This analysis included data from one of the participating industries in the J-ECOH Study (electrical machinery and apparatus manufacturing), where detailed information on physical activity has been collected as a part of periodic health check-ups since 2006.

The study protocol was approved by the Ethics Committee of the National Center for Global Health and Medicine, Japan. The purpose and procedure of the J-ECOH Study were announced by using posters. Participants were allowed to refuse the provision of their data to the study. This procedure conforms to the Japanese Ethical Guidelines for Epidemiological Research for observational studies that use existing data.

\section{Participants}

In Japan, employers are obliged to organize health check-ups for their employees at least once per year under the Industrial Safety and Health Act. A total of 23,248 workers aged 20 to 65 years received health check-ups (comprehensive type) between April 2006 and March 2007 (baseline period) and had data for serum creatinine. We excluded workers with CKD (defined as an estimated glomerular filtration rate [eGFR] of $<60 \mathrm{~mL} / \mathrm{min} / 1.73 \mathrm{~m}{ }^{2}$ and/or proteinuria [+, 2+, or $3+$ on dipstick [19]]; $n=1,510)$; with self-reported cancer $(n=179)$; with an eGFR of $\geq 200$ $\mathrm{mL} / \mathrm{min} / 1.73 \mathrm{~m}^{2}$ (due to possible measurement errors[20]; $\mathrm{n}=5$ ); with incomplete information on physical activity $(\mathrm{n}=$ $2,424)$; and with engagement in an unspecified activity only during leisure $(n=489)$. We further excluded workers who attended no subsequent health check-ups or who had no measurement of eGFR or proteinuria in a subsequent health check-up ( $n=1,973)$. Finally, 17,331 participants $(15,544$ men and 1,787 women) were included in the analyses (Figure S1). 


\section{Assessment of physical activity during leisure, commuting, and work}

Details of the information collected for leisure-time physical activity have been described in the literature [18, 21, 22]. Participants were asked to choose up to 3 activities among a list of 20 exercise or sports activities and the frequency (times per month) and duration of time per occasion (minutes) for each activity. If participants engaged in activities not listed in the questionnaire, they were instructed to choose an activity of similar intensity from the list. Of the 20 exercise or sports activities in the list, one activity named "Other" was not used for further analysis.

The metabolic equivalent (MET; $1 \mathrm{MET}=1 \mathrm{kcal}$ per $\mathrm{h}$ per $\mathrm{kg}$ of body weight) value for each activity was determined according to Ainsworth's compendium of physical activities [23]. Of the 19 activities, 12 (walking not for work or commuting, walking fast not for work or commuting, golf practice, golf, baseball, softball, bike cycling, table tennis, pang pong, badminton, muscle strength training, and radio gymnastics) were classified as moderate activities (3 to 5.9 MET), and 7 (light jogging [approximately $6 \mathrm{~min} / \mathrm{km}$ ], jogging, swimming, soccer, tennis, aerobics, and jump rope) were classified as vigorous activities ( $\geq 6 \mathrm{MET}$ ). Leisure-time physical activity was defined as the product of intensity (MET) and duration of exercise (h), and the calculated MET-h per week of each individual was placed into one of the 4 categories-inactive (0 MET-h), low ( $>0$ to $<7.5$ MET-h), moderate ( $\geq 7.5$ to $<16.5$ MET-h), or high ( $\geq 16.5$ MET-h) -which roughly accords with the classification of current physical activity guideline [24].

Occupational physical activity was assessed by the question To what extent is your work physically demanding? with the following response options: mostly sedentary, mostly standing, walking often, or fairly active. We combined the 2 categories in the middle (i.e., mostly standing and often walking) to increase the statistical power.

Commuting physical activity was assessed by the self-reported duration of walking to and from work (in minutes) and categorized as $<20,20$ to $<40$, and $\geq 40 \mathrm{~min}$ for the analysis, which is similar to categories in other studies in Japan [18, 25].

\section{Ascertainment of chronic kidney disease cases}

CKD was assessed by using the data of annual health check-ups from baseline to March 2019 and defined as an eGFR of $<60 \mathrm{~mL} / \mathrm{min} / 1.73 \mathrm{~m}^{2}$ and/or proteinuria (+, 2+, or 3+ on dipstick) [19]. eGFR was calculated by using the following formula established by the working group of the Japanese CKD Initiative: eGFR $\left(\mathrm{mL} / \mathrm{min} / 1.73 \mathrm{~m}^{2}\right)=1.94 \times($ serum creatinine $)^{-1.094} \times(\text { age })^{-0.287} \times(0.739$ if female) [26]. Serum creatinine was measured by the enzyme method with an autoanalyzer (Hitachi 7600, Japan). Proteinuria was tested by dipsticks and by using an autoanalyzer (Siemens Healthcare, Japan) and categorized as negative,, $\pm 1+, 2+$, and $3+$ (corresponding to protein levels of undetectable, trace, $30 \mathrm{mg} / \mathrm{dL}, 100 \mathrm{mg} / \mathrm{dL}$, and $\geq 300 \mathrm{mg} / \mathrm{dL}$, respectively). The date of check-up when CKD was first identified was the incidence date of CKD.

\section{Covariates}

The covariates included eGFR, age, sex, smoking status, alcohol consumption, job position, overtime work, shift work, commuting mode, and sleep duration, hypertension, diabetes, history of cardiovascular disease, dyslipidemia, hyperuricemia, and body mass index (BMI) at baseline. We refer to the online Supplementary Appendix 1 for data collection methods, which have been described in previous papers [18, 22, 27].

\section{Statistical analysis}

We calculated person-years of follow-up for each participant, from the date of the baseline health check-up to the date of health check-up when the CKD was first identified or the date of the last health check-up, whichever came first. We 
ran a Cox proportional hazards regression to calculate hazard ratios (HRs) and 95\% confidence intervals (Cls) for the association between leisure-time, occupational, and commuting physical activity and time to incident CKD. We adjusted for covariates in a stepwise manner.

Model 1 included baseline eGFR, age (continuous, years), and sex. Model 2 additionally adjusted for smoking status (never, former, or current), alcohol consumption $(0,>0$ to $<2$, or $\geq 2$ go/day), job position (high or low), overtime work ( $<45$, 45 to $<60,60$ to $<80,80$ to $<100$, or $\geq 100 \mathrm{~h} /$ month), shift work (yes or no), primary commuting mode (walking, bicycling, train/bus, or car/motorbike), and sleep duration ( $<5,5$ to $<6,6$ to $<7$, or $\geq 7 \mathrm{~h}$ per day). Model 3 further adjusted for potential mediators, such as hypertension, diabetes, history of cardiovascular disease, dyslipidemia, hyperuricemia, and $\operatorname{BMI}\left(<18.5,18.5\right.$ to $<25.0,25.0$ to $<30.0$, or $\left.\geq 30.0 \mathrm{~kg} / \mathrm{m}^{2}\right)$. Model 4 adjusted for other types of physical activity, which were mutually adjusted.

The trend association between leisure-time physical activity and risk of CKD was assessed by assigning the median dose of leisure-time physical activity in each category and treating this variable as continuous. For the trend for occupational physical activity, we assigned a score of 1-3 to sedentary work, walking or standing during work, and fairly active during work, respectively. For commuting physical activity, we assigned 10, 30, and 50 min to increasing categories of walking to and from work ( $<20,20$ to $<40$, and $\geq 40 \mathrm{~min})$. We also conducted sensitivity analyses and excluded participants with $<2$ years of follow-up term for the aforementioned major analyses.

To test the effect modification by hypertension, diabetes, obesity (BMl<25 or $\geq 25 \mathrm{~kg} / \mathrm{m}^{2}$ ), baseline eGFR (60 to 89 or $\geq 90 \mathrm{~mL} / \mathrm{min} / 1.73 \mathrm{~m}^{2}$ ), occupational (sedentary work or not), and commuting physical activity ( $<20$ or $\geq 20 \mathrm{~min}$ ), we conducted subgroup analyses in a fully adjusted model (model 4). Those subgroup analyses were repeated between occupational or commuting physical activity and CKD onset. The proportional hazards assumption was examined using Schoenfeld residuals, and all covariates agreed with the proportional hypothesis except for age and baseline eGFR.

The proportion of missing data for each covariate was as follows: smoking status ( $0.4 \%)$, job position (3.3\%), monthly overtime work $(3.6 \%)$, shiftwork $(2.9 \%)$, primary commuting mode $(0.1 \%)$, sleep duration $(0.2 \%)$, diabetes $(0.2 \%)$, dyslipidemia (0.02\%), and hyperuricemia (0.04\%). We performed multiple imputations by using the chained equation method, with multinomial logistic regression for imputation of smoking status, monthly overtime work, primary commuting mode, and sleep duration; and logistic regression for job position, shiftwork, diabetes, dyslipidemia, and hyperuricemia. The imputation used all the variables involved in all the analytic models, including the outcome variables of time-to-event and event status. The 20 imputed data sets were generated, and the results were combined by using Rubin's rules. All statistical analyses were performed with Stata/MP version 16.1 (Stata Corp., College Station, Texas). The statistical significance was set at a 2-sided $\mathrm{P}$ value of 0.05 for all analyses.

\section{Results}

At baseline, the mean (standard deviation) age of the 17,331 participants was 42.8 (10.0) years, and $90 \%$ were men; $65 \%$ of the participants were physically inactive during leisure, and $54 \%$ were sedentary during work. Table 1 shows the characteristics of the study population by baseline leisure-time physical activity categories. The proportions of men and those with diabetes were higher among participants with higher leisure-time physical activity. By contrast, the level of baseline eGFR and the ratios of the current smoker and long overtime work decreased with increasing leisure-time physical activity. The baseline characteristics stratified by occupational or commuting physical activity are presented in Table S1-2. 
Table 1

Baseline characteristics of the participants, according to the volume of leisure-time physical activity

\begin{tabular}{|c|c|c|c|c|}
\hline & \multicolumn{4}{|c|}{ Leisure-time physical activity (MET-h/week) } \\
\hline & Inactive & Low & Moderate & High \\
\hline & $\begin{array}{l}\text { (0 MET- } \\
\text { h/week) }\end{array}$ & $\begin{array}{l}\text { (>0 to }<7.5 \mathrm{MET}- \\
\text { h/week) }\end{array}$ & $\begin{array}{l}(7.5 \text { to }<16.5 \mathrm{MET}- \\
\mathrm{h} / \text { week) }\end{array}$ & $\begin{array}{l}(\geq 16.5 \mathrm{MET}- \\
\mathrm{h} / \text { week })\end{array}$ \\
\hline Participants & $n=11,170$ & $\mathrm{n}=2,896$ & $\mathrm{n}=1,901$ & $n=1364$ \\
\hline Male sex, n (\%) & $9,826(88.0)$ & 2,669 (92.2) & 1,763 (92.7) & $1,286(94.3)$ \\
\hline Age, years & $42.7(9.8)$ & $42.2(10.0)$ & $43.1(10.3)$ & $43.6(10.9)$ \\
\hline eGFR, mL/min/1.73 m² & $89.1(16.1)$ & $87.3(15.1)$ & $85.9(15.1)$ & $85.8(14.9)$ \\
\hline $\mathrm{BMI}, \mathrm{kg} / \mathrm{m}^{2}$ & $23.4(3.5)$ & $23.6(3.4)$ & $23.8(3.2)$ & $23.6(3.1)$ \\
\hline \multicolumn{5}{|l|}{ Smoking status, n (\%) } \\
\hline Never & $3,793(34.0)$ & $998(34.5)$ & $648(34.1)$ & $509(37.3)$ \\
\hline Former & $1,918(17.2)$ & $593(20.5)$ & $458(24.1)$ & $316(23.2)$ \\
\hline Current & $5,407(48.4)$ & $1,298(44.8)$ & $791(41.6)$ & $537(39.4)$ \\
\hline \multicolumn{5}{|l|}{ Alcohol intake, n (\%) } \\
\hline None & $3,682(33.0)$ & $774(26.7)$ & 504 (26.5) & $353(25.9)$ \\
\hline$>0$ to $<2$ go/day & $5,099(45.6)$ & $1,513(52.2)$ & $955(50.2)$ & $673(49.3)$ \\
\hline$\geq 2$ go/day & $2,389(21.4)$ & $609(21.0)$ & $442(23.3)$ & $338(24.8)$ \\
\hline High job position, n (\%) & $1,788(16.0)$ & $536(18.5)$ & $418(22.0)$ & $257(18.8)$ \\
\hline $\begin{array}{l}\text { Long overtime work ( } \\
45 \mathrm{~h} / \text { month) }\end{array}$ & $4,000(35.8)$ & $1,033(35.7)$ & $647(34.0)$ & $410(30.1)$ \\
\hline Shift work, n (\%) & $2,929(26.2)$ & $723(25.0)$ & $426(22.4)$ & $328(24.0)$ \\
\hline \multicolumn{5}{|l|}{ Commuting mode, $\mathrm{n}(\%)$} \\
\hline Walking & $1,578(14.1)$ & $392(13.5)$ & $257(13.5)$ & $191(14.0)$ \\
\hline Cycling & $655(5.9)$ & $175(6.0)$ & $126(6.6)$ & $94(6.9)$ \\
\hline $\begin{array}{l}\text { Bus/train (public } \\
\text { transportation) }\end{array}$ & $2,439(21.8)$ & $596(20.6)$ & 359 (18.9) & $234(17.2)$ \\
\hline Car/motorbike & $6,490(58.1)$ & $1,731(59.8)$ & $1,159(61.0)$ & $844(61.9)$ \\
\hline $\begin{array}{l}\text { Sleep duration of }<6 \mathrm{~h} / \text { day, } \mathrm{n} \\
(\%)\end{array}$ & $5,708(51.1)$ & $1,361(47.0)$ & $910(47.9)$ & $620(45.5)$ \\
\hline Hypertension, n (\%) & 1,489 (13.3) & $364(12.6)$ & $255(13.4)$ & $186(13.6)$ \\
\hline Diabetes, n (\%) & $802(7.2)$ & $242(8.4)$ & $173(9.1)$ & $123(9.0)$ \\
\hline History of CVD, n (\%) & $65(0.6)$ & $16(0.6)$ & $16(0.8)$ & $9(0.7)$ \\
\hline Dyslipidemia, n (\%) & $5,111(45.8)$ & $1,274(44.0)$ & $837(44.0)$ & $522(38.3)$ \\
\hline
\end{tabular}




\section{Leisure-time physical activity (MET-h/week)}

\begin{tabular}{|c|c|c|c|c|}
\hline Hyperuricemia, n (\%) & 2,218 (19.9) & $596(20.6)$ & $388(20.4)$ & $262(19.2)$ \\
\hline \multicolumn{5}{|c|}{$\begin{array}{l}\text { Walking to and from work, } \mathrm{n} \\
(\%)\end{array}$} \\
\hline 0 to $<20 \mathrm{~min}$ & $5,979(53.5)$ & $1,547(53.4)$ & $1,070(56.3)$ & $786(57.6)$ \\
\hline 20 to $<40 \mathrm{~min}$ & 3,557 (31.8) & $912(31.5)$ & $543(28.6)$ & $405(29.7)$ \\
\hline$\geq 40 \mathrm{~min}$ & $1,634(14.6)$ & $437(15.1)$ & $288(15.1)$ & $173(12.7)$ \\
\hline \multicolumn{5}{|l|}{$\begin{array}{l}\text { Occupational physical } \\
\text { activity, } \mathrm{n}(\%)\end{array}$} \\
\hline Sedentary & $5,867(52.5)$ & $1,604(55.4)$ & $1,130(59.4)$ & $726(53.2)$ \\
\hline Standing or walking & 4,095 (36.7) & $989(34.2)$ & $594(31.2)$ & $472(34.6)$ \\
\hline Fairly active & $1,208(10.8)$ & $303(10.5)$ & $177(9.3)$ & $166(12.2)$ \\
\hline \multicolumn{5}{|c|}{$\begin{array}{l}\text { Data are shown as the mean (standard deviation) for continuous variables and as a number (percentages) for } \\
\text { categorical variables. The proportion of missing data for each covariate was as follows: smoking status }(0.4 \%) \text {, job } \\
\text { position }(3.3 \%) \text {, monthly overtime work }(3.6 \%) \text {, shiftwork }(2.9 \%) \text {, primary commuting mode }(0.1 \%) \text {, sleep duration } \\
(0.2 \%) \text {, diabetes }(0.2 \%) \text {, dyslipidemia }(0.02 \%) \text {, and hyperuricemia }(0.04 \%) \text {. }\end{array}$} \\
\hline \multicolumn{5}{|c|}{ BMI, body mass index; CVD, cardiovascular disease; eGFR, estimated glomerular filtration rate. } \\
\hline
\end{tabular}

During 147,752 person-years of follow-up, 4,013 (23\%) participants developed CKD, with an overall incidence rate of 27.2 cases per 1,000 person-years. The median follow-up was 10.6 years (range $0.2-13.0$ ). Table 2 shows the associations of leisure-time, occupational, and commuting physical activity with incident CKD. Leisure-time physical activity was not significantly related to the risk of developing CKD in any adjusted models. By contrast, occupational physical activity was observed as a significant association in all models. 
Table 2

Hazard ratios of chronic kidney disease, according to leisure-time, occupational, and commuting physical activity.

\begin{tabular}{|c|c|c|c|c|c|c|}
\hline & Cases/Subjects & $\begin{array}{l}\text { Person- } \\
\text { years }\end{array}$ & Model $1^{b}$ & Model $2^{c}$ & Model $3^{d}$ & Model $4^{\mathrm{e}}$ \\
\hline \multicolumn{7}{|l|}{ Leisure-time physical activity } \\
\hline Inactive (0 MET-h/week) & $2,557 / 11,170$ & 94,647 & $\begin{array}{l}1.00 \\
\text { (reference) }\end{array}$ & $\begin{array}{l}1.00 \\
\text { (reference) }\end{array}$ & $\begin{array}{l}1.00 \\
\text { (reference) }\end{array}$ & $\begin{array}{l}1.00 \\
\text { (reference) }\end{array}$ \\
\hline $\begin{array}{l}\text { Low (>0 to }<7.5 \text { MET- } \\
\text { h/week) }\end{array}$ & $643 / 2,896$ & 25,572 & $\begin{array}{l}0.92(0.84- \\
1.00)\end{array}$ & $\begin{array}{l}0.93 \\
(0.85- \\
1.02)\end{array}$ & $\begin{array}{l}0.94 \\
(0.86- \\
1.03)\end{array}$ & $\begin{array}{l}0.94 \\
(0.86- \\
1.03)\end{array}$ \\
\hline $\begin{array}{l}\text { Moderate }(7.5 \text { to }<16.5 \\
\text { MET-h/week) }\end{array}$ & $474 / 1,901$ & 16,116 & $\begin{array}{l}1.04 \\
(0.94- \\
1.15)\end{array}$ & $\begin{array}{l}1.06 \\
(0.96- \\
1.17)\end{array}$ & $\begin{array}{l}1.06 \\
(0.96- \\
1.17)\end{array}$ & $\begin{array}{l}1.06 \\
(0.96- \\
1.17)\end{array}$ \\
\hline \multirow[t]{2}{*}{ High ( $\geq 16.5$ MET-h/week) } & $339 / 1,364$ & 11,417 & $\begin{array}{l}1.04 \\
(0.92- \\
1.16)\end{array}$ & $\begin{array}{l}1.05 \\
(0.94- \\
1.18)\end{array}$ & $\begin{array}{l}1.08 \\
(0.96- \\
1.21)\end{array}$ & $\begin{array}{l}1.08 \\
(0.96- \\
1.21)\end{array}$ \\
\hline & & $\begin{array}{l}P \text { for } \\
\text { trend }^{a}\end{array}$ & 0.402 & 0.224 & 0.118 & 0.116 \\
\hline \multicolumn{7}{|l|}{ Occupational physical activity } \\
\hline Sedentary & $2,403 / 9,327$ & 79,584 & $\begin{array}{l}1.00 \\
\text { (reference) }\end{array}$ & $\begin{array}{l}1.00 \\
\text { (reference) }\end{array}$ & $\begin{array}{l}1.00 \\
\text { (reference) }\end{array}$ & $\begin{array}{l}1.00 \\
\text { (reference) }\end{array}$ \\
\hline Standing/Walking & $1,246 / 6,150$ & 51,974 & $\begin{array}{l}0.88 \\
(0.82- \\
0.94)\end{array}$ & $\begin{array}{l}0.87 \\
(0.80- \\
0.94)\end{array}$ & $\begin{array}{l}0.88 \\
(0.82- \\
0.95)\end{array}$ & $\begin{array}{l}0.88 \\
(0.86- \\
0.96)\end{array}$ \\
\hline \multirow[t]{2}{*}{ Fairly active } & $364 / 1,854$ & 16,194 & $\begin{array}{l}0.88 \\
(0.79- \\
0.98)\end{array}$ & $\begin{array}{l}0.87 \\
(0.77- \\
0.99)\end{array}$ & $\begin{array}{l}0.91 \\
(0.81- \\
1.03)\end{array}$ & $\begin{array}{l}0.91 \\
(0.81- \\
1.03)\end{array}$ \\
\hline & & $\begin{array}{l}P \text { for } \\
\text { trend }^{a}\end{array}$ & $<0.001$ & 0.001 & 0.012 & 0.012 \\
\hline \multicolumn{7}{|c|}{ Walking for commuting to and from work } \\
\hline$<20 \min$ & $2,013 / 9,382$ & 80,581 & $\begin{array}{l}1.00 \\
\text { (reference) }\end{array}$ & $\begin{array}{l}1.00 \\
\text { (reference) }\end{array}$ & $\begin{array}{l}1.00 \\
\text { (reference) }\end{array}$ & $\begin{array}{l}1.00 \\
\text { (reference) }\end{array}$ \\
\hline 20 to $<40 \mathrm{~min}$ & $1,334 / 5,417$ & 46,106 & $\begin{array}{l}1.10 \\
(1.03- \\
1.18)\end{array}$ & $\begin{array}{l}1.06 \\
(0.98- \\
1.15)\end{array}$ & $\begin{array}{l}1.06 \\
(0.98- \\
1.15)\end{array}$ & $\begin{array}{l}1.06 \\
(0.98- \\
1.15)\end{array}$ \\
\hline \multirow[t]{2}{*}{$\geq 40 \min$} & $666 / 2,532$ & 21,066 & $\begin{array}{l}1.14 \\
(1.04- \\
1.25)\end{array}$ & $\begin{array}{l}1.07 \\
(0.97- \\
1.20)\end{array}$ & $\begin{array}{l}1.09 \\
(0.98- \\
1.21)\end{array}$ & $\begin{array}{l}1.09 \\
(0.98- \\
1.21)\end{array}$ \\
\hline & & $\begin{array}{l}P \text { for } \\
\text { trend }^{\text {a }}\end{array}$ & 0.001 & 0.124 & 0.091 & 0.093 \\
\hline
\end{tabular}




\section{Cases/Subjects}

Person-
years

Model $1^{b}$

years

Data are shown as the hazard ratio (95\% confidence interval).

a $P$ value for the linear trend was calculated by using the Cox proportional hazards regression and assigning each category of physical activity as a continuous variable.

${ }^{\mathrm{b}}$ Model 1 was adjusted for baseline estimated glomerular filtration rate (60 to 89 or $\geq 90 \mathrm{~mL} / \mathrm{min} / 1.73 \mathrm{~m}^{2}$ ), age (continuous), and sex.

${ }^{\mathrm{c}}$ Model 2 was further adjusted for baseline smoking status (never, former, or current), alcohol consumption ( 0 , $>0$ to $<2$, or $\geq 2 \mathrm{go} /$ day), job position (high or low), overtime work ( $<45,45$ to $<60,60$ to $<80,80$ to $<100$, or $\geq 100 \mathrm{~h}$ ), shift work (yes or no), commuting mode (walking, bicycling, train/bus, or car/motorbike), and sleep duration $(<5,5$ to $<6$, 6 to $<7$, or $\geq 7 \mathrm{~h}$ per day).

d Model 3 was further adjusted for potential mediators, including baseline hypertension, diabetes, history of cardiovascular disease, dyslipidemia, hyperuricemia, and body mass index $(<18.5,18.5$ to $<25.0,25.0$ to $<30.0$, or $\left.\geq 30.0 \mathrm{~kg} / \mathrm{m}^{2}\right)$.

e Model 4 was further adjusted for the other types of physical activity (i.e., leisure-time physical activity $(0,>0$ to $<$ $7.5,7.5$ to $<16.5$, or $\geq 16.5$ MET-h/week), occupational physical activity (sedentary, standing or walking, and fairly physically activity), or walking for commuting to and from work (<20 min, 20 to $<40 \mathrm{~min}$, or $\geq 40 \mathrm{~min}]$ ).

Relative to the participants who were sedentary during work, those who were standing or walking and fairly active during work had HRs of 0.88 (95\% Cl: 0.82-0.95) and 0.91 (0.81-1.03), respectively, after adjustment of potential mediators in Model 3 ( $p$ for trend 0.012). The association was virtually unchanged after additional adjustment for the other domains of physical activity (Model 4). Walking for commuting to and from work was significantly associated with CKD in Model 1 (adjusted for age, sex, baseline eGFR); however, the association was no longer statistically significant after adjustment of other covariates (Models 2-4). In the sensitivity analyses excluding participants with < 2 years follow-up (1,550 participants, including 824 incident cases), the associations virtually did not change. That is, sedentary during work remained a significant association with CKD risk (Table S3).

Subgroup analyses of leisure-time physical activity (Table 3) showed that the interactions by hypertension, diabetes, obesity, and baseline kidney function were not statistically significant ( $p$ for interaction $>0.05$ ). Additionally, the HRs associated with leisure-time physical activity did not differ across subgroups of other domains of physical activity, defined by occupational physical activity (sedentary or active during work) or commuting ( $<20$ min or $\geq 20$ min for walking to and from work). Regarding the subgroup analyses of occupational and commuting physical activity, the interactions with other forms of physical activity were null results (Tables S4 and S5). 
Table 3

Hazard ratios of chronic kidney disease according to the volume of leisure-time physical activity in subgroups.

\begin{tabular}{|c|c|c|c|c|c|c|c|}
\hline \multirow[t]{3}{*}{ Subgroups } & \multirow[t]{3}{*}{ Cases/Subjects } & \multirow{3}{*}{$\begin{array}{l}\text { Person- } \\
\text { years }\end{array}$} & \multicolumn{4}{|c|}{ Leisure-time physical activity (MET-h/week) } & \multirow{3}{*}{$\begin{array}{l}P \text { for } \\
\text { interaction }\end{array}$} \\
\hline & & & Inactive & Low & Moderate & High & \\
\hline & & & $\begin{array}{l}\text { (0 MET- } \\
\text { h/week) }\end{array}$ & $\begin{array}{l}(>0 \text { to }< \\
7.5 \\
\text { MET- } \\
\text { h/week) }\end{array}$ & $\begin{array}{l}\text { (7.5 to < } \\
16.5 \\
\text { MET- } \\
\text { h/week) }\end{array}$ & $\begin{array}{l}\text { ( } \geq 16.5 \\
\text { MET- } \\
\text { h/week) }\end{array}$ & \\
\hline \multicolumn{8}{|l|}{ Hypertension } \\
\hline Yes & $799 / 2,294$ & 15,989 & $\begin{array}{l}1.00 \\
\text { (Reference) }\end{array}$ & $\begin{array}{l}0.92 \\
(0.78- \\
1.13)\end{array}$ & $\begin{array}{l}0.96 \\
(0.77- \\
1.19)\end{array}$ & $\begin{array}{l}0.81 \\
(0.61- \\
1.07)\end{array}$ & \multirow[t]{2}{*}{0.077} \\
\hline No & $3,214 / 15,037$ & 131,764 & $\begin{array}{l}1.00 \\
\text { (Reference) }\end{array}$ & $\begin{array}{l}0.91 \\
(0.83- \\
1.00)\end{array}$ & $\begin{array}{l}1.04 \\
(0.93- \\
1.17)\end{array}$ & $\begin{array}{l}1.12 \\
(0.99- \\
1.27)\end{array}$ & \\
\hline \multicolumn{8}{|l|}{ Diabetes } \\
\hline Yes & $458 / 1,340$ & 9,338 & $\begin{array}{l}1.00 \\
\text { (Reference) }\end{array}$ & $\begin{array}{l}0.95 \\
(0.74- \\
1.23)\end{array}$ & $\begin{array}{l}1.34 \\
(1.02- \\
1.75)\end{array}$ & $\begin{array}{l}0.80 \\
(0.55- \\
1.16)\end{array}$ & \multirow[t]{2}{*}{0.161} \\
\hline No & $3,543 / 15,956$ & 138,141 & $\begin{array}{l}1.00 \\
\text { (Reference) }\end{array}$ & $\begin{array}{l}0.93 \\
(0.85- \\
1.03)\end{array}$ & $\begin{array}{l}1.02 \\
(0.91- \\
1.13)\end{array}$ & $\begin{array}{l}1.13 \\
(1.00- \\
1.28)\end{array}$ & \\
\hline \multicolumn{8}{|l|}{ Obesity } \\
\hline $\mathrm{BMI} \geq 25 \mathrm{~kg} / \mathrm{m}^{2}$ & $1,541 / 5,054$ & 41,180 & $\begin{array}{l}1.00 \\
\text { (Reference) }\end{array}$ & $\begin{array}{l}0.88 \\
(0.76- \\
1.01)\end{array}$ & $\begin{array}{l}1.05 \\
(0.90- \\
1.23)\end{array}$ & $\begin{array}{l}0.97 \\
(0.80- \\
1.18)\end{array}$ & \multirow[t]{2}{*}{0.136} \\
\hline $\mathrm{BMI}<25 \mathrm{~kg} / \mathrm{m}^{2}$ & $2,472 / 12,277$ & 106,572 & $\begin{array}{l}1.00 \\
\text { (Reference) }\end{array}$ & $\begin{array}{l}0.97 \\
(0.87- \\
1.08)\end{array}$ & $\begin{array}{l}1.06 \\
(0.93- \\
1.20)\end{array}$ & $\begin{array}{l}1.15 \\
(1.00- \\
1.32)\end{array}$ & \\
\hline \multicolumn{8}{|l|}{ Baseline eGFR } \\
\hline $\begin{array}{l}60 \text { to } \\
89 \mathrm{~mL} / \mathrm{min} / 1.73 \mathrm{~m}^{2}\end{array}$ & $2,843 / 10,248$ & 84,227 & $\begin{array}{l}1.00 \\
\text { (Reference) }\end{array}$ & $\begin{array}{l}0.92 \\
(0.83- \\
1.02)\end{array}$ & $\begin{array}{l}1.07 \\
(0.96- \\
1.20)\end{array}$ & $\begin{array}{l}1.11 \\
(0.98- \\
1.27)\end{array}$ & \multirow[t]{2}{*}{0.190} \\
\hline $\begin{array}{l}\geq \\
90 \mathrm{~mL} / \mathrm{min} / 1.73 \mathrm{~m}^{2}\end{array}$ & $1,170 / 7,083$ & 63,525 & $\begin{array}{l}1.00 \\
\text { (Reference) }\end{array}$ & $\begin{array}{l}0.98 \\
(0.83- \\
1.14)\end{array}$ & $\begin{array}{l}1.04 \\
(0.85- \\
1.27)\end{array}$ & $\begin{array}{l}0.93 \\
(0.73- \\
1.18)\end{array}$ & \\
\hline \multicolumn{8}{|c|}{ Occupational physical activity } \\
\hline Sedentary & $2,403 / 9,327$ & 79,584 & $\begin{array}{l}1.00 \\
\text { (Reference) }\end{array}$ & $\begin{array}{l}1.01 \\
(0.90- \\
1.12)\end{array}$ & $\begin{array}{l}1.14 \\
(1.00- \\
1.29)\end{array}$ & $\begin{array}{l}1.07 \\
(0.92- \\
1.24)\end{array}$ & \multirow[t]{2}{*}{0.424} \\
\hline Active $^{a}$ & $1,610 / 8,004$ & 68,168 & $\begin{array}{l}1.00 \\
\text { (Reference) }\end{array}$ & $\begin{array}{l}0.84 \\
(0.73- \\
0.97)\end{array}$ & $\begin{array}{l}0.91 \\
(0.77- \\
1.09)\end{array}$ & $\begin{array}{l}1.08 \\
(0.91- \\
1.29)\end{array}$ & \\
\hline \multicolumn{8}{|c|}{ Walking to and from work } \\
\hline$<20 \min$ & $2,013 / 9,382$ & 80,581 & $\begin{array}{l}1.00 \\
\text { (Reference) }\end{array}$ & $\begin{array}{l}0.92 \\
(0.81- \\
1.04)\end{array}$ & $\begin{array}{l}1.09 \\
(0.95- \\
1.25)\end{array}$ & $\begin{array}{l}1.10 \\
(0.95- \\
1.08)\end{array}$ & 0.586 \\
\hline
\end{tabular}

Page 10/15 
time spent sitting at work was inversely associated with eGFR, and more time spent carrying objects or being active at work was positively related to eGFR [30]. Additionally, the Health ABC study showed that prolonged television watching (> 3 hours/day) was associated with a faster decline in kidney function and a higher incidence of CKD in older adults [11]. Prolonged sitting time has been linked to the unfavorable profile of insulin sensitivity, inflammation, and lipid metabolism, independent of whether individuals fulfill physical activity guidelines [31, 32]. Because of the scarce prospective evidence on the association between occupational physical activity and development of CKD, additional cohort studies are necessary to determine if engaging sedentary work is associated with a higher risk of CKD.

We observed no association between the duration of walking on commuting to and from work and CKD incident in the participants and among the participants engaging in sedentary work (Table S5). By contrast, the cross-sectional study in Northern Ireland showed better renal function was associated with higher physical activity while commuting to or from work [30]. In that study, commuting physical activity was assessed based on detailed information (intensity, frequency, and duration) and expressed in MET-hours/week. Thus, further prospective studies with a detailed assessment of commuting physical activity are necessary.

This study has several strengths, for example, the large size of the cohort, long-term follow-up, and annual assessments with data on serum creatinine and proteinuria. In addition, we adjusted for comprehensive covariates, including sleep duration and work-related factors, which the literature had not considered.

However, several of this study's limitations warrant mention. First, physical activity was assessed with unvalidated selfreported questionnaires. Nonetheless, the questionnaires used in our study are similar to previously validated and reproducible questionnaires for leisure, occupational, and commuting activities [33-35]. Second, we used only baseline information on physical activity, and the non-differential misclassification in physical activity due to within-individual variability during follow-up would lead the results toward the null. Third, residual confounding and unmeasured confounders, such as diet, might have affected the risk of CKD. Finally, we defined an incident of CKD by using a single point measurement of eGFR and/or proteinuria. Thus, because the clinical diagnosis of CKD is determined based on 2 measures taken at least 3 months apart [19], our criteria for CKD has a sensitivity of $100 \%$ but low specificity, distorting the associations toward the null.

\section{Conclusions}

We demonstrated that leisure-time and commuting physical activity were not associated with the development of CKD in this large-scale working population and that engaging in sedentary work was related to the risk of CKD incident.

\section{Abbreviations}

BMI: body mass index; Cl: confidence interval; CKD: Chronic kidney disease; CVD: cardiovascular disease; eGFR: estimated glomerular filtration rate; HR: hazard ratio; J-ECOH: Japan Epidemiology Collaboration on Occupational Health; MET: metabolic equivalent.

\section{Declarations}

\section{Ethics approval and consent to participate}

The study protocol was approved by the Ethics Committee of the National Center for Global Health and Medicine, Japan. The purpose and procedure of the J-ECOH Study were announced by using posters. Participants were allowed to

Page $12 / 15$ 
refuse the provision of their data to the study. This procedure conforms to the Japanese Ethical Guidelines for Epidemiological Research for observational studies that use existing data.

\section{Consent for publication}

Not applicable.

\section{Availability of data and materials}

The datasets generated and/or analysed during the current study are not publicly available due ethical restrictions and participant confidentiality concerns, but de-identified data are available from Dr. Mizoue (Department of Epidemiology and Prevention, Center for Clinical Sciences, National Center for Global Health and Medicine, Tokyo, Japan) to qualified researchers on reasonable request.

\section{Competing interests}

The authors declared no conflict of interest. T.N., T Honda, Shuichiro Y, and T Hayashi are occupational physicians in the participating company.

\section{Funding}

This study was supported by grants from the industrial Health Foundation, Industrial Disease Clinical Research Grants (grant numbers 140202-01, 150903-01, 170301-01), the Japan Society for the Promotion of Science (JSPS KAKENHI JP16H05251), and the National Center for Global Health and Medicine (28-shi-1206).

\section{Authors' contributions}

Research idea and study design: Shohei Y; data acquisition: TN, T Honda, Shuichiro Y, and T Hayashi; data analysis/interpretation: Shohei Y, YI, KK, TM, and TM; statistical analysis: Shohei Y; supervision or mentorship: YI, KK, and TM. Each author contributed important intellectual content during manuscript drafting or revision, accepts personal accountability for the author's own contributions, and agrees to ensure that questions pertaining to the accuracy or integrity of any portion of the work are appropriately investigated and resolved.

\section{Acknowledgments}

The authors thank Maki Konishi (National Center for Global Health and Medicine) for data management, and Rika Osawa (National Center for Global Health and Medicine) for administrative support.

\section{References}

1. Bikbov B, Purcell CA, Levey AS, Smith M, Abdoli A, Abebe M, et al: Global, regional, and national burden of chronic kidney disease, 1990-2017: a systematic analysis for the Global Burden of Disease Study 2017. The Lancet 2020.

2. Foreman KJ, Marquez N, Dolgert A, Fukutaki K, Fullman N, McGaughey M, et al. Forecasting life expectancy, years of life lost, and all-cause and cause-specific mortality for 250 causes of death: reference and alternative scenarios for 2016-40 for 195 countries and territories. The Lancet. 2018;392(10159):2052-90. 
3. Locatelli F, Vecchio LD, Pozzoni P. The importance of early detection of chronic kidney disease. Nephrol Dial Transplant. 2002;17(suppl_11):2-7.

4. Luyckx VA, Tonelli M, Stanifer JW. The global burden of kidney disease and the sustainable development goals. Bull World Health Organ. 2018;96(6):414.

5. Inker LA, Astor BC, Fox CH, Isakova T, Lash JP, Peralta CA, et al. KDOQI US Commentary on the 2012 KDIGO Clinical Practice Guideline for the Evaluation and Management of CKD. Am J Kidney Dis. 2014;63(5):713-35.

6. Lear SA, Hu W, Rangarajan S, Gasevic D, Leong D, Iqbal R, et al. The effect of physical activity on mortality and cardiovascular disease in 130† $₫ 000$ people from 17 high-income, middle-income, and low-income countries: the PURE study. The Lancet. 2017;390(10113):2643-54.

7. Linke A. Effects of exercise training upon endothelial function in patients with cardiovascular disease. Front Biosci. 2008;13(13):424.

8. Reisin E, Jack AV. Obesity and hypertension: mechanisms, cardio-renal consequences, and therapeutic approaches. Med Clin North Am. 2009;93(3):733-51.

9. Hallan S, De Mutsert R, Carlsen S, Dekker FW, Aasarød K, Holmen J. Obesity, Smoking, and Physical Inactivity as Risk Factors for CKD: Are Men More Vulnerable? Am J Kidney Dis. 2006;47(3):396-405.

10. White SL, Dunstan DW, Polkinghorne KR, Atkins RC, Cass A, Chadban SJ. Physical inactivity and chronic kidney disease in Australian adults: The AusDiab study. Nutr Metab Cardiovasc Dis. 2011;21(2):104-12.

11. Hawkins M, Newman AB, Madero M, Patel KV, Shlipak MG, Cooper J, et al. TV Watching, but Not Physical Activity, Is Associated With Change in Kidney Function in Older Adults. J Phys Activ Health. 2015;12(4):561-8.

12. Glavinovic T, Ferguson T, Komenda P, Rigatto C, Duhamel TA, Tangri N, et al. CKD and Sedentary Time: Results From the Canadian Health Measures Survey. Am J Kidney Dis. 2018;72(4):529-37.

13. Guo C, Tam T, Bo Y, Chang L-Y, Lao XQ, Thomas GN. Habitual physical activity, renal function and chronic kidney disease: a cohort study of nearly 200000 adults. Br J Sports Med 2020:bjsports-2019-100989.

14. Csizmadi I, Lo Siou G, Friedenreich CM, Owen N, Robson PJ. Hours spent and energy expended in physical activity domains: Results from The Tomorrow Project cohort in Alberta, Canada. Int J Behav Nutr Phys Act. 2011;8(1):110.

15. Jha V, Garcia-Garcia G, Iseki K, Li Z, Naicker S, Plattner B, et al. Chronic kidney disease: global dimension and perspectives. The Lancet. 2013;382(9888):260-72.

16. Webster AC, Nagler EV, Morton RL, Masson P. Chronic Kidney Disease. The Lancet. 2017;389(10075):1238-52.

17. Hori A, Nanri A, Sakamoto N, Kuwahara K, Nagahama S, Kato N, et al. Comparison of Body Mass Index, Waist Circumference, and Waist-to-Height Ratio for Predicting the Clustering of Cardiometabolic Risk Factors by Age in Japanese Workers. Circ J. 2014;78(5):1160-8.

18. Kuwahara K, Honda T, Nakagawa T, Yamamoto S, Akter S, Hayashi T, et al: Associations of leisure-time, occupational, and commuting physical activity with risk of depressive symptoms among Japanese workers: a cohort study. Int J Behav Nutr Phys Act 2015, 12(1).

19. Essential points from Evidence-based Clinical Practice Guidelines for Chronic Kidney Disease. 2018. Clin Exp Nephrol 2019, 23(1):1-15.

20. Levey AS, Stevens LA, Schmid CH, Zhang Y, Castro AF, Feldman HI, et al. A New Equation to Estimate Glomerular Filtration Rate. Ann Intern Med. 2009;150(9):604.

21. Honda T, Kuwahara K, Nakagawa T, Yamamoto S, Hayashi T, Mizoue T. Leisure-time, occupational, and commuting physical activity and risk of type 2 diabetes in Japanese workers: a cohort study. BMC Public Health 2015, 15(1).

22. Kuwahara K, Honda T, Nakagawa T, Yamamoto S, Akter S, Hayashi T, et al. Leisure-time exercise, physical activity during work and commuting, and risk of metabolic syndrome. Endocrine. 2016;53(3):710-21.

Page 14/15 
23. Ainsworth BE, Haskell WL, Herrmann SD, Meckes N, Bassett DR Jr, Tudor-Locke C, et al. 2011 Compendium of Physical Activities: a second update of codes and MET values. Med Sci Sports Exerc. 2011;43(8):1575-81.

24. Piercy KL, Troiano RP, Ballard RM, Carlson SA, Fulton JE, Galuska DA, et al. The Physical Activity Guidelines for Americans. JAMA. 2018;320(19):2020.

25. Hayashi T, Tsumura K, Suematsu C, Okada K, Fujii S, Endo G. Walking to Work and the Risk for Hypertension in Men: The Osaka Health Survey. Ann Intern Med. 1999;131(1):21-6.

26. Matsuo S, Imai E, Horio M, Yasuda Y, Tomita K, Nitta K, et al. Revised Equations for Estimated GFR From Serum Creatinine in Japan. Am J Kidney Dis. 2009;53(6):982-92.

27. Kuwahara K, Noma H, Nakagawa T, Honda T, Yamamoto S, Hayashi T, et al: Association of changes in commute mode with body mass index and visceral adiposity: a longitudinal study. Int J Behav Nutr Phys Act 2019, 16(1).

28. Foster MC, Hwang S-J, Massaro JM, Jacques PF, Fox CS, Chu AY. Lifestyle Factors and Indices of Kidney Function in the Framingham Heart Study. Am J Nephrol. 2015;41(4-5):267-74.

29. Tremblay MS, Aubert S, Barnes JD, Saunders TJ, Carson V, Latimer-Cheung AE, et al: Sedentary Behavior Research Network (SBRN) - Terminology Consensus Project process and outcome. Int J Behav Nutr Phys Act 2017, 14(1).

30. Esquirol Y, Tully M, Ruidavets J-B, Fogarty D, Ferrieres J, Quinn M, et al. Could occupational physical activity mitigate the link between moderate kidney dysfunction and coronary heart disease? Int J Cardiol.

2014;177(3):1036-41.

31. Leitzmann MF, Jochem C, Schmid D. Sedentary behaviour epidemiology: Springer; 2017.

32. Hamilton MT, Healy GN, Dunstan DW, Zderic TW, Owen N. Too little exercise and too much sitting: Inactivity physiology and the need for new recommendations on sedentary behavior. Curr Cardiovasc Risk Rep.

2008;2(4):292-8.

33. Matthews CE. Reproducibility and Validity of the Shanghai Women's Health Study Physical Activity Questionnaire. Am J Epidemiol. 2003;158(11):1114-22.

34. Tsubono Y, Tsuji I, Fujita K, Nakaya N, Hozawa A, Ohkubo T, et al. Validation of Walking Questionnaire for Population-based Prospective Studies in Japan: Comparison with Pedometer. J Epidemiol. 2002;12(4):305-9.

35. Kurtze N, Rangul V, Hustvedt B-E, Flanders WD. Reliability and validity of self-reported physical activity in the NordTrøndelag Health Study (HUNT 2). Eur J Epidemiol. 2007;22(6):379-87.

\section{Supplementary Files}

This is a list of supplementary files associated with this preprint. Click to download.

- STROBEchecklistcohort.doc

- SupplementalTables.docx

- SupplementaryAppendix1.docx

- FigureS1.pptx 